\title{
Production of 'Ubá' mango tree submitted to rejuvenation pruning and fertilized with nitrogen
}

\author{
Luiz Carlos Chamhum Salomão ${ }^{1}$, Dalmo Lopes de Siqueira ${ }^{1}$, \\ Danielle Fabíola Pereira da Silva ${ }^{1}$
}

\begin{abstract}
The rejuvenation pruning or plant prune is a practice used in fruits species such mango tree, whose plants can exceed ten meters heigh, compromising the implementation of practices such as spraying and harvesting. This study aimed to evaluate the resumption of production of adult 'Ubá' mango trees, previously pruned and subjected to fertilization with increasing levels of nitrogen over five seasons. The experiment was conducted in Visconde do Rio Branco, MG. Nineteen years old mango trees were pruned and reduced to the primary branches, about $1.5 \mathrm{~m}$ above the ground. Excess shoots were removed, remaining five to six branches per tree. In the year in which the plants were pruned, the nitrogen fertilization was initiated with different doses, divided into three equal fractions, between October of one year and February of the following year. Annually were applied per plant, $160 \mathrm{~g}$ of $\mathrm{P}_{2} \mathrm{O}_{5}$ in the form of simple superphosphate, 350 $\mathrm{g}$ of $\mathrm{K}_{2} \mathrm{O}$ in the form of potassium chloride, according to the results of the soil analysis, and 0 , $175,350,525$ and $700 \mathrm{~g}$ of $\mathrm{N}$ in the form of urea. Two years after pruning the plants returned to production, and in the first five crops, we quantified the production in $\mathrm{kg}$ per plant and the number of fruits per plant. The production of the mango trees was already stable in the fifth crop or seven years after pruning. The dose of nitrogen resulting in the maximum yield was $238.9 \mathrm{~g} / \mathrm{plant}$.
\end{abstract}

Index terms: Mangifera indica $\mathrm{L}$., urea, mineral nutrition

\section{Produção da mangueira 'Ubá' submetida à poda de rejuvenescimento e adubada com nitrogênio}

Corresponding author:

1salomao@ufv.br

Received: Janeiro 03, 2017.

Accepted : October 02, 2017.

Copyright: All the contents of this journal, except where otherwise noted, is licensed under a Creative Commons Attribution License.

\section{$(\mathrm{cc}) \mathrm{EY}$}

\begin{abstract}
Resumo - A poda de rejuvenescimento ou recepagem é prática utilizada em espécies frutíferas como a mangueira, cujas plantas podem ultrapassar dez metros de altura, comprometendo a execução de práticas como pulverizações e colheita. O trabalho teve como objetivo avaliar a retomada da produção de mangueiras 'Ubá', previamente recepadas e submetidas à adubação com doses crescentes de nitrogênio, em cinco safras. O experimento foi instalado em Visconde do Rio Branco-MG. Mangueiras com 19 anos de idade foram recepadas na altura das pernadas, acerca de $1,5 \mathrm{~m}$ acima do solo. Posteriormente, foram conduzidas com cinco a seis pernadas cada. No ano em que foi feita a recepagem iniciaram-se as adubações nitrogenadas diferenciais das mangueiras, parceladas em três frações iguais, entre outubro de um ano e fevereiro do ano seguinte. Foram aplicados anualmente, por planta, $160 \mathrm{~g}$ de $\mathrm{P}_{2} \mathrm{O}_{5}$, na forma de superfosfato simples, $350 \mathrm{~g}$ de $\mathrm{K}_{2} \mathrm{O}$, na forma de cloreto de potássio, conforme os resultados da análise de solo, e $0 ; 175 ; 350 ; 525$ e $700 \mathrm{~g}$ de N, na forma de ureia. As mangueiras voltaram a frutificar dois anos após a recepagem e foram avaliadas nas cinco primeiras safras, quantificando-se a produção, em kg por planta, e o número de frutos produzidos por planta. A produção das mangueiras já estava estável na quinta safra ou sete anos após a recepagem. A dose de nitrogênio que resultou em máxima produção foi de $238,9 \mathrm{~g} /$ planta.
\end{abstract}

Termos para indexação: Mangifera indica L., ureia, nutrição mineral. 
The Mango tree (Mangifera indica L.) is a species of tropical climate originating in South Asia and cultivated in more than one hundred countries of tropical and subtropical climate in the world. In Brazil the mango tree is cultivated mainly in Northeast and Southeast regions (IBGE, 2017), with potential for expansion on both cultivated area and yield. In Minas Gerais, specifically in the 'Zona da Mata Mineira' stands the cultivar 'Ubá' which grows spontaneously in all the municipalities of the region.

Most of the oldest orchards of this cultivar were formed by seminiferous propagation, and the plants grow freely being able to surpass $20 \mathrm{~m}$ of height, which makes the sanitary management and fruits harvest difficult. In addition, these orchards do not receive a regular supply of nutrients, contributing to low yield, ranging from 5 to $7 \mathrm{t} / \mathrm{ha}$.

Fertilization is one of the cultural practices that can interfere with production, and the response of the plant is dependent on soil characteristics, orchard management and climatic conditions. Nitrogen is an element that participates in several essential compounds for the vegetative and reproductive growth of mango and stimulates branch growth and fixation, weight and fruit production (BALLY, 2009). In mango, according to literature review presented by Bally (2009), nitrogen combined with potassium stimulates the production of terminal floriferous branches. Foliar nitrogen concentrations between 1.0 and $1.5 \mathrm{~g} /$ $100 \mathrm{~g}$ of the dry matter are considered optimal for the mango; however, above these values stimulate vegetative growth in detriment of flowering, fixation and fruit quality. The demand for mineral nutrients from mango is high. Souza (2007) estimated the quantities of macronutrients exported by fruits harvested from the 'Tommy Atkins' mango in $198.9 \mathrm{~g} \mathrm{~N} /$ plant, $21.1 \mathrm{~g} \mathrm{P} /$ plant, $212.7 \mathrm{~g} \mathrm{~K} /$ plant, $27.1 \mathrm{~g} \mathrm{Ca} /$ plant, $19.6 \mathrm{~g} \mathrm{Mg} /$ plant and $12.0 \mathrm{~g} \mathrm{~S}$ / plant, considering the production of 400 fruits per plant. No information was found in the scientific literature on the adequate nitrogen dose for the recovery of mango trees submitted to rejuvenation pruning. In this way, the objective of this study was to evaluate the production, over five crops, of 'Ubá' adult mango trees, previously pruned and submitted to fertilization with increasing doses of nitrogen.

The experiment was conducted at the Sementeira Experimental Farm, in Visconde do Rio Branco, MG - Brazil (latitude $21^{\circ} 00^{\prime} 37^{\prime \prime} \mathrm{S}$, longitude 42 $50^{\prime} 26^{\prime \prime} \mathrm{W}$, altitude $352 \mathrm{~m}$, Aw climate according to classification of Köppen and Geiger, average annual temperature at $22.6^{\circ} \mathrm{C}$ and annual mean precipitation of $1,248 \mathrm{~mm}$ ), belonging to the Federal University of Viçosa. The soil of the experimental area is a dystrophic Red-Yellow Latosol with wavy topography. Their chemical characteristics prior to the implantation of the experiment, obtained from collected samples under the crown of the trees at depths of 0 to $0.2 \mathrm{~m}$ and 0.2 to $0.4 \mathrm{~m}$, are shown in Table 1 .

The 'Ubá' mango orchard, grafted on an unidentified rootstock had plants spaced $6 \mathrm{~m}$ apart between rows $x 8 \mathrm{~m}$ between plants. At age 19, at the end of winter, the mango trees were pruned with chainsaw at the height of about $1.5 \mathrm{~m}$ above the ground. In the two years following the pruning, the trees were cleared, leaving 5 to 6 main branches per tree. After that, the plants were allowed to grow freely.

In the years prior to the pruning, mango trees were fertilized according to the recommendations by Soil Fertility Commission of Minas Gerais (1978), however, they were not irrigated, nor pruned, fruit thinning or any type of sanitary control.

The experiment was conducted in a randomized complete block design with five treatments ( $\mathrm{N}$ doses) and five replications with one plant per sample unit. External and internal borders were used, that is, both the experimental area as a whole, and each tree individually were surrounded by other 'Ubá' mangoes that were not submitted to differential nitrogen fertilizations.

After the pruning, differential fertilization of the mangoes was started based on recommendations by Soil Fertility Commission of Minas Gerais (1978). It was applied $160 \mathrm{~g}$ of $\mathrm{P}_{2} \mathrm{O}_{5}$ in form of single superphosphate and $350 \mathrm{~g}$ of $\mathrm{K}_{2} \mathrm{O}$ per plant per year in the form of potassium chloride. For nitrogen, in addition to the recommended dose of $350 \mathrm{~g}$ per plant were used doses of $0,175,525$ and $700 \mathrm{~g}$ per plant as urea. Nitrogen and potassium were divided into three equal fractions applied between October of one year and February of the following year. The fertilizers were applied in a semicircle, under the projection of the plants crown in the highest part of the land, after the opening of a groove with about $5 \mathrm{~cm}$ depth. Only the useful plants of the experiment were fertilized. The border plants did not receive any fertilization during the whole experimental period. During the experimental period no manure or limestone was given to the plants.

Two years after the pruning, the mango tress began to bloom again. Data were collected from the first five crops after the pruning. During this period, the production was quantified in kg per plant, and the number of fruits produced per plant.

The average weight of the fruits was obtained by dividing the production by the number of fruits per plant. The yield and number of fruits per plant over the years were compared by the Tukey test at $5 \%$ probability. The Pearson correlation was also calculated between number and average fruit weight at $5 \%$ probability. Comparison of the effects of $\mathrm{N}$ doses on yield and number of fruits was done by means of regression analysis. Statistical analyzes were performed using the Genes software (CRUZ, 2013).

In each dose of nitrogen used the production and the number of harvested fruits differed according to the years of evaluation (Table 2). The production of mango trees in $\mathrm{kg}$ / plant and number of fruits per plant showed a clear alternate bearing with crops 2 and 4 being of low production, and crops 3 and 5 being of high production (Table 2). This alternation was less pronounced in the plants fertilized with $175 \mathrm{~g}$ of $\mathrm{N}$. The similarity between 
the yields of crops 3 and 5 suggests that the productive potential of mango tress was reached in the third crop. The results obtained in crop 5 showed the high productive potential of the orchard under study with mean yield of $136.8 \mathrm{~kg} /$ plant or $28.5 \mathrm{t} / \mathrm{ha}$, considering the spacing of $6 \mathrm{~m} \mathrm{x} 8 \mathrm{~m}$ or 208 plants / ha. This value surpasses the average regional yield of 'Ubá' mango tree which is 5 to $7 \mathrm{t} / \mathrm{ha}$, and even the national average which was $15.2 \mathrm{t} /$ ha in 2015 (IBGE, 2017).

The production and number of fruits per plant reached the maximum point with the dose of 238.9 $\mathrm{g}$ of $\mathrm{N} /$ plant / year (Figure 1). Reviewing the most appropriate doses of $\mathrm{N}$ for mango culture, Bally (2009) cites that maximum yield is reached at 800 to $1,100 \mathrm{~g} /$ plant / year. For the State of Minas Gerais, Souza et al. (1999) recommend the supply of $350 \mathrm{~g}$ of N / plant / year, considering an adult orchard with expected yield of 10 $\mathrm{t} /$ ha. In a study carried out in the State of Rio Grande do Norte with the 'Tommy Atkins' mango tree, Caldas (2009) obtained maximum yield of $14 \mathrm{t} /$ ha with 175 $\mathrm{g} \mathrm{N} /$ plant / year. The obtained results are closer to the recommendations of national publications than the data obtained in other producing regions and make it clear that the mango tree is less nitrogen demanding than other fruit trees such as avocado and citrus. For avocados aged six years or older, Lahav et al (2013) recommend 200 to 250 $\mathrm{kg}$ of N / ha and for citrus, Siqueira and Salomão (2017) recommend $380 \mathrm{~g}$ of $\mathrm{N} /$ plant, also in orchards with six or more years of age.

On the other hand, Fernandes and Nascimento (2004) report the export of $1,037 \mathrm{~g} \mathrm{~N} / \mathrm{t}$ fruits, considering several cultivars. Also, taking into account the average yield obtained in this study in crop 5 which was $136.8 \mathrm{~kg}$ / plant, this would be the equivalent to the export of $142 \mathrm{~g}$ of $\mathrm{N} /$ plant. Therefore, the supply of $238.9 \mathrm{~g}$ of N / plant would be able to supply this demand with a surplus of 97 $\mathrm{g}$ for vegetative growth and normal losses by leaching, volatilization, etc. It should be noted that the fertilizations with nitrogen, phosphorus and potassium described in the methodology were repeated for a period of seven consecutive years. Although nitrogen is mobile in soil and its effects do not accumulate from year to year, some residual effects persist through the nutrient plant cycling (RAIJ, 1983).

According to El-Otmani et al. (2004), on years of high production, methods such as fruit thinning, branching, exogenous plant regulator applications and harvest anticipation to control fruit loading contribute to reduce alternate bearing. In the low yield years, flowering and fruit fixation can be enhanced with mango tree flowering induction techniques described by Crane et al. (2009).

There was variation on fruits average weight over the years being smaller in the years of greater production (Table 2). The negative correlation between the number of fruits per plant and the average weight of the fruit (Figure 2) suggests the possibility of increasing the average weight of the fruits destined to natural consumption through the practice of thinning in the years of high production. This practice has been used successfully in species such as apple (HEHNEN et al., 2012), mandarin (El-ZEFTAWI, 1976) and persimmon fruit (OJIMA et al., 1985).

It was concluded that the production of mango tree in $\mathrm{kg}$ / plant and number of fruits per plant was already stable in the fifth crop or seven years after the pruning. The nitrogen dose that resulted in maximum production was $238.9 \mathrm{~g} \mathrm{~N} /$ plant / year. Nitrogen fertilization reduced the tendency of alternate bearing in 'Ubá' mangoes.

Table 1. Result of the soil chemical analysis from the experimental area located at the Experimental Farm Sementeira, in Visconde do Rio Branco, Minas Gerais ${ }^{1}$

\begin{tabular}{|c|c|c|c|c|c|c|c|c|c|c|c|c|c|}
\hline \multirow{2}{*}{$\begin{array}{l}\text { Deep } \\
(\mathrm{cm})\end{array}$} & Carb & $\mathrm{pH}$ & $\mathrm{P}$ & $\mathrm{K}$ & $\mathrm{Al}$ & $\mathrm{Ca}$ & $\mathrm{Mg}$ & $\mathrm{H}+\mathrm{Al}$ & $\mathrm{BS}$ & $\begin{array}{c}\mathrm{Cl} \\
\text { Efet }\end{array}$ & $\begin{array}{l}\text { C } \\
\text { Total }\end{array}$ & V & M \\
\hline & $\%$ & \multicolumn{3}{|c|}{$-\mathrm{mg} / \mathrm{dm}^{3}-$} & & & & cmolc/ & & & & \multicolumn{2}{|c|}{------ \% ----- } \\
\hline $0-20$ & 2.38 & 5.5 & 16.3 & 122 & 0.2 & 1.8 & 0.6 & 3.6 & 2.69 & 2.89 & 6.29 & 42.8 & 6.9 \\
\hline $20-40$ & 2.22 & 5.4 & 13.7 & 62 & 0.1 & 1.7 & 0.6 & 3.0 & 2.43 & 2.53 & 5.43 & 44.7 & 4.0 \\
\hline
\end{tabular}


Table 2. Production ( $\mathrm{kg}$ / plant), number of fruits per plant and average fruit weight (g) of 'Ubá' mango trees fertilized with different nitrogen doses in the first five crops after pruning

\begin{tabular}{|c|c|c|c|c|c|c|}
\hline \multirow{2}{*}{$\mathrm{N}$ doses (g / plant) } & \multicolumn{5}{|c|}{ Evaluation period } & \multirow[b]{2}{*}{ Total } \\
\hline & Crop 1 & Crop 2 & Crop 3 & Crop 4 & Crop 5 & \\
\hline \multicolumn{7}{|c|}{ 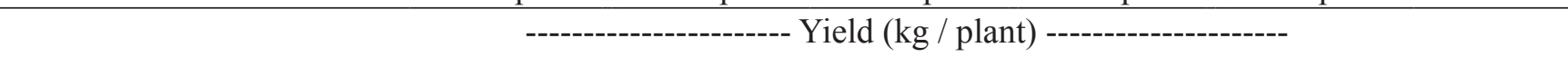 } \\
\hline 0 & $5.82 b$ & $48.1 \mathrm{ab}$ & $109.80 \mathrm{a}$ & $55.26 \mathrm{ab}$ & $131.83 \mathrm{a}$ & 350.81 \\
\hline 175 & $44.62 b$ & $66.92 b$ & $146.80 \mathrm{a}$ & $103.85 \mathrm{a}$ & $148.77 \mathrm{a}$ & 510.96 \\
\hline 350 & $40.34 b$ & $58.32 \mathrm{~b}$ & $127.80 \mathrm{a}$ & $72.64 b$ & $133.14 \mathrm{a}$ & 432.24 \\
\hline 525 & $44.98 b$ & $44.48 b$ & $143.40 \mathrm{a}$ & $62.22 \mathrm{ab}$ & $142.75 \mathrm{a}$ & 437.83 \\
\hline 700 & $48.45 b$ & $49.06 \mathrm{~b}$ & $133.80 \mathrm{a}$ & $75.07 \mathrm{ab}$ & $127.34 \mathrm{a}$ & 433.72 \\
\hline \multicolumn{7}{|c|}{ 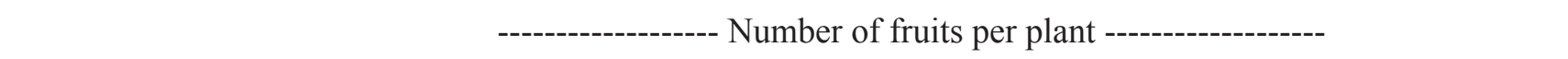 } \\
\hline 0 & $46.6 \mathrm{c}$ & $425.4 \mathrm{bc}$ & $949.4 \mathrm{ab}$ & $354.2 b c$ & $1195.4 \mathrm{a}$ & 2971.0 \\
\hline 175 & $347.2 b$ & $596.4 \mathrm{ab}$ & $1309.6 \mathrm{a}$ & $715.4 \mathrm{ab}$ & $1360.8 \mathrm{a}$ & 4329.4 \\
\hline 350 & $316.4 \mathrm{~b}$ & $506.0 \mathrm{ab}$ & $1160.4 \mathrm{ab}$ & $503.2 \mathrm{ab}$ & $1211.2 \mathrm{a}$ & 3697.1 \\
\hline 525 & $358.6 b$ & $365.4 \mathrm{~b}$ & $1262.4 \mathrm{a}$ & $443.6 \mathrm{~b}$ & $1309.2 \mathrm{a}$ & 3739.2 \\
\hline 700 & $403.4 b$ & $432.2 b$ & $1197.0 \mathrm{a}$ & $483.8 \mathrm{~b}$ & $1152.0 \mathrm{a}$ & 3668.4 \\
\hline \multicolumn{7}{|c|}{------------------- Average fruit weight (g) ---------------- } \\
\hline 0 & 124.9 & 113.1 & 115.6 & 156.0 & 110.3 & 124.0 \\
\hline 175 & 128.5 & 112.2 & 112.1 & 145.1 & 109.3 & 121.4 \\
\hline 350 & 127.5 & 115.2 & 110.1 & 144.3 & 109.9 & 121.4 \\
\hline 525 & 125.4 & 121.7 & 113.6 & 140.2 & 109.0 & 122.0 \\
\hline 700 & 120.1 & 113.5 & 111.7 & 155.2 & 110.6 & 122.2 \\
\hline
\end{tabular}

Means followed by the same letter in the row do not differ by the Tukey test $(\mathrm{p}<0.05)$.
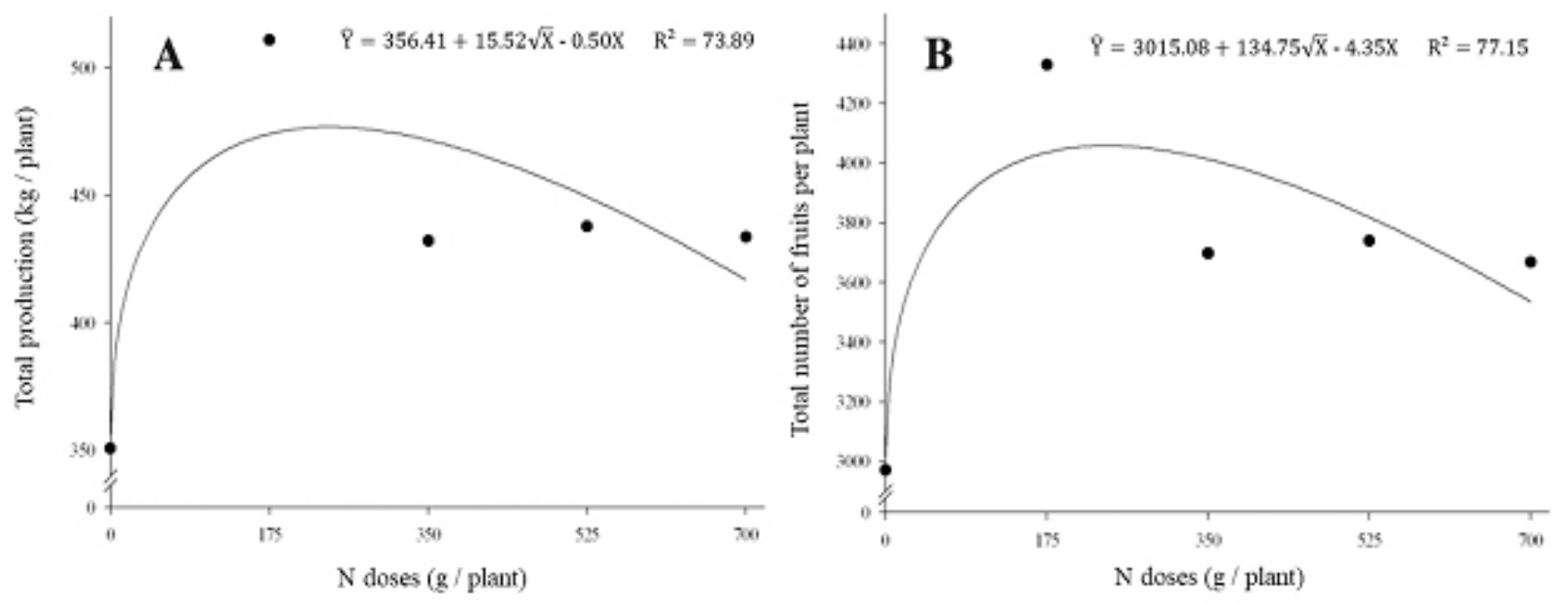

Figure 1. Cumulative production ( $\mathrm{kg} / \mathrm{plant}$ ) (A) and cumulative number of fruits (B) of 'Ubá' mango trees, in the first five crops after pruning, as a function of nitrogen doses applied to the soil. 


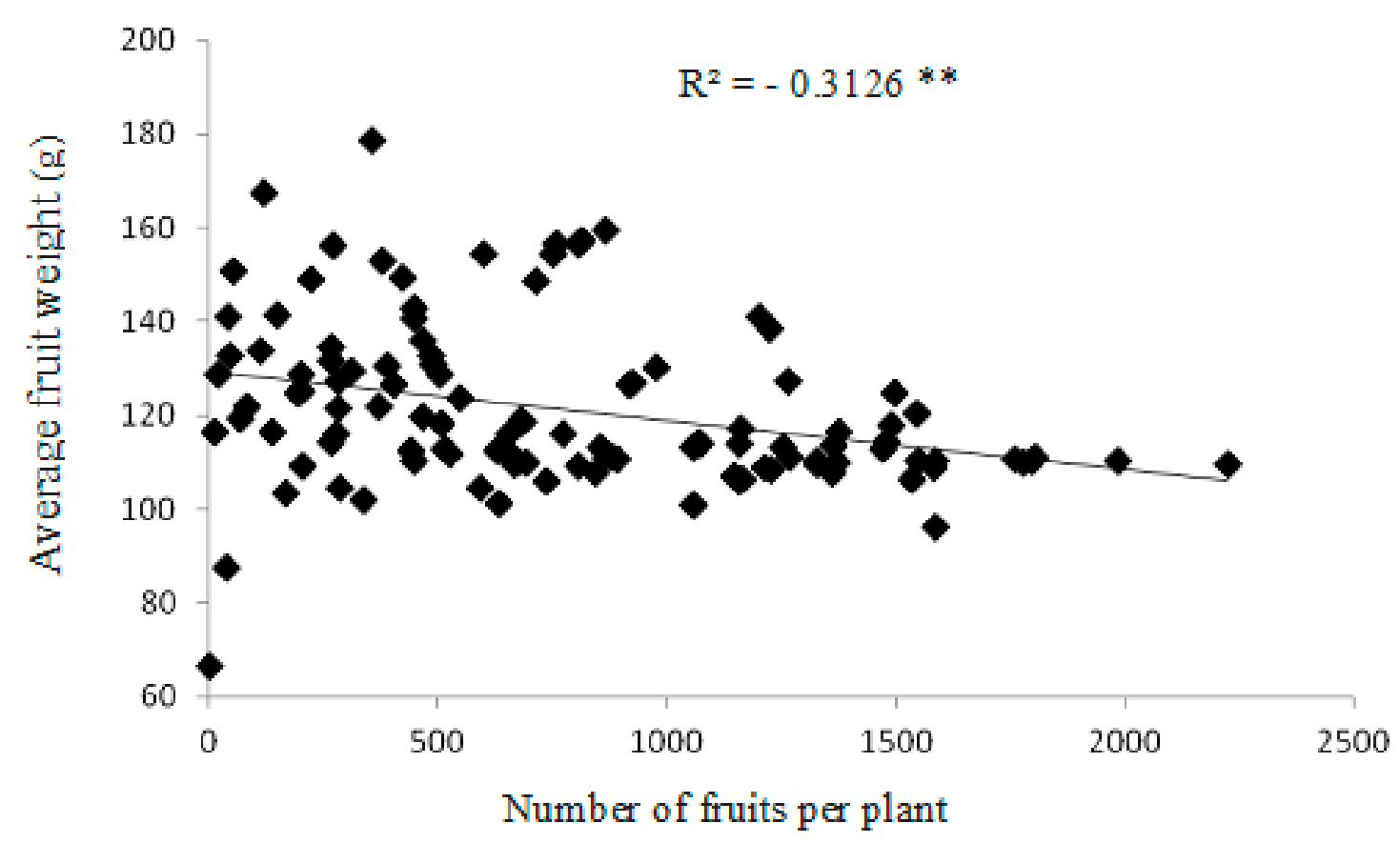

Figure 2. Pearson correlation between fruit number and average fruit weight of 'Ubá' mango trees fertilized with different doses of nitrogen $(* *$ Significant at $1 \%$ probability, by t test).

\section{Acknowledgments}

We would like to thank the National Council for Scientific and Technological Development (CNPq) for granting research grants to the first two authors.

\section{References}

BALLY, I.S.E. Crop production: mineral nutrition. In: LITZ, R. E. (Ed) The mango: botany, production and uses. Wallingford: CABI, 2009. p. 404-431.

CALDAS, A.V.C. Produção e qualidade de manga sob adubação nitrogenada e potássica no Vale do Açu. 2009. 79 f. Dissertação de Mestrado. Universidade Federal Rural do Semi-Árido, Mossoró, 2009.

COMISSÃO DE FERTILIDADE DO SOLO DO ESTADO DE MINAS GERAIS Recomendações para uso de corretivos e fertilizantes em Minas Gerais $-3^{\mathrm{a}}$ aproximação. Belo Horizonte: Epamig, 1978. 80 p.

CRANE, J.H.; SALAZAR-GARCIA, S.; LIN, T.S.; QUEIROZ PINTO, A.C.; SHU, Z.H. Crop production: management. In: LITZ, R. E. (Ed) The mango: botany, production and uses. Wallingford: CABI, 2009. p. 432483.
CRUZ, C.D. GENES - a software package for analysis in experimental statistics and quantitative genetics. Acta Scientiarum. Agronomy, v. 35, n. 3, p. 271-276, 2013.

El-OTMANI, M. Improved use of foliar urea on Clementine mandarin to manipulate cropping in a sustainable production system. Acta Horticulturae, v. 632, p. 167-175, 2004.

El-ZEFTAWI, B.M. Effects of ethephon and 2,4,5-T on fruit size, rind pigments and alternate bearing of 'Imperial' mandarin. Scientia Horticulturae, v. 5, n. 4, p. 315320, 1976.

FERNANDES, F.M.; NASCIMENTO, V.M. Fertilidade do solo e nutrição da mangueira. In: ROZANE, D.E.; DAREZZO, R.J.; AGUIAR, R.L.; AGUILERA, G.H.A.; ZAMBOLIM, L. (Eds) Manga: produção integrada, industrialização e comercialização. Viçosa: UFV, 2004. p. 179-198.

HEHNEN, D.; HANRAHAN, I.; LEWIS, K.; MCFERSON, J.; BLANKE, M. Mechanical flower thinning improves fruit quality of apples and promotes consistent bearing. Scientia Horticulturae, v. 134, p. 241-244, 2012.

IBGE. Instituto Brasileiro de Geografia e Estatística. Rendimento médio de lavouras permanentes. 2015. Disponível em: https://sidra.ibge.gov.br/tabela/1613\#resultado. Acessado em: 19 abr. 2017. 
LAHAV, E.; WHILEY, A.W.; TURNER, D.W. Irrigation and mineral nutrition. In: SCHAFFER, B.; WOLSTENHOLME, B.N.; WHILEY, A.W. The avocado: botany, production and uses, 2 ed. Wallingford: CABI, 2013. P. 301-341.

OJIMA, M.; DALL'ORTO, F.A.C.; BARBOSA, W.; TOMBOLATO, A.F.C.; RIGITANO, O. Frutificação alternada em caqui cultivar Pomelo (IAC 6-22). Bragantia, v. 4, n. 1, p. 481-486, 1985.

SIQUEIRA, D.L.; SALOMÃO, L.C.C. Citros - do plantio à colheita. Viçosa: UFV, 2017. 278 p.

SOUZA, F. V. Curva de crescimento e exportação de nutrientes e sódio por frutos de mangueira Palmer, Haden e Tommy Atkins. 2007. 54 f. Dissertação de mestrado. Universidade Estadual Paulista, Jaboticabal, 2007.
SOUZA, M.; GUIMARÃES, P.T.G.; CARVALHO, J.G.; FRAGOAS, J.C. Mangueira. In: RIBEIRO, A.C.; GUIMARÃES, P.T.G.; ALVAREZ, V.V.H. (Eds) Recomendações para o uso de corretivos e fertilizantes em Minas Gerais, $5^{\text {a }}$ aproximação. Viçosa, MG: CFSEMG, cap.18, 1999. p.239-241.

RAIJ, B. Avaliação da fertilidade do solo. Piracicaba: Instituto da Potassa \& Fosfato, 1983. 142 p. 